\title{
Effectiveness of Averrhoa Bilimbi Leaf Extract on Spermatogenic Cells of Mice (Mus Musculus L.) Hyperglycemia
}

\author{
Ida Ayu Manik Damayanti \\ Institut Teknologi dan Kesehatan Bali, Indonesia \\ Corresponding author email: idaayumanikk@gmail.com \\ Putu Indrayoni \\ Institut Teknologi dan Kesehatan Bali, Indonesia \\ Ni Wayan Sukma Antari \\ Institut Teknologi dan Kesehatan Bali, Indonesia \\ Anak Agung Istri Mas Padmiswari \\ Institut Teknologi dan Kesehatan Bali, Indonesia
}

\begin{abstract}
The purpose of this study was to determine the effect of giving Averrhoa bilimbi leaf extract on sperm quality of diabetic mice. This research is a pure experimental (true experimental) with a post-test-only control group design approach. This research was conducted by giving Averrhoa bilimbi leaf extract as a treatment for 42 days in male mice. Sperm quality parameters observed included viability, abnormalities, motility in sperm. In all variables, the results of the data showing a normal distribution with a p-value $>0.05$ were then carried out with a parametric test using one-way ANOVA. Averrhoa bilimbi leaf extract can increase the number of spermatogenic cells in male mice with hyperglycemia.
\end{abstract}

Keywords---Averrhoa bilimbi, hyperglycemia, spermatogenic cells

\section{Introduction}

Diabetes mellitus is a metabolic disease characterized by an increase in blood glucose levels exceeding normal (hyperglycemia) and impaired carbohydrate, fat, and protein metabolism associated with a lack of sensitivity and/or insulin secretion and progressive changes in the structure of pancreatic beta cells. Uncontrolled DM sufferers can cause severe damage to body tissues, such as nerves and blood vessels. According to Perkeni 2015, a person is said to be hyperglycemic if the fasting blood glucose level (GDP) is $>100 \mathrm{mg} / \mathrm{dl}$. Blood glucose checks can be done on blood glucose during fasting and blood glucose during fasting. Temporary blood glucose is a blood glucose test that is carried out every time of the day regardless of the last food eaten and the person's body condition, while fasting blood glucose is an examination of blood glucose levels that is carried out after the patient has fasted for 8-10 hours. DM sufferers need treatment. throughout his life to reduce symptoms, prevent disease progression, and prevent complications from developing (Kaličanin \& Velimirović, 2012; Kasturi et al., 2008). This causes a decrease in the diameter of the seminiferous tubules, a decrease in the number of Leydig cells and Sertoli cells. This decrease in number causes disruption of reproductive hormone function which will later cause disruption of spermatogenesis resulting in abnormalities of spermatozoa quality (concentration, morphology, motility). This study aims to analyze the effect of giving wuluh starfruit extract to reduce blood glucose levels in wistar rats. This research is also useful for providing information to the public about the efficacy of star fruit in lowering blood glucose levels, further researching the benefits of star fruit as medicine to enrich traditional medicine, pharmacology, pharmacy, and biochemistry (Sisein, 2014; Vicari \& Calogero, 2001; Gülçin, 2012). 


\section{Methods}

This type of research is pure experimental (true experimental) with a post-test-only control group design approach. This research was conducted by giving wuluh starfruit leaf extract as a treatment for 42 days to male mice induced by alloxan. The sample to be used in this study was calculated using the Federer formula (1991). After the treatment was given for 42 days, the spermatogenic cells were observed which included: a. spermatogonia, b. spermatocytes, c. spermatids, d. tubular diameter (Kurup \& Mini, 2017; Tan, et al., 2005). Data analysis using the SPSS for windows version 21.0 program which includes a normality test on all variables in each group on all observations, using the Kolmogroov-Smirnov test to determine whether the research data is normally distributed or not with a P-value > 0.05 , as well as homogeneous data with a test homogeneity with P-value $>0.05$. In all variables, the results of the data showing a normal distribution with a p-value $>0.05$ were then carried out with a parametric test using one-way ANOVA.

\section{Results}

The results showed that the administration of starfruit leaf extract had different effects on each observation variable of body weight and spermatogenic cells in male mice (Mus musculus L.). Observations can be shown in tables, graphs, pictures, and analysis results.

Table 1

Mean and standard deviation of body weight, and spermatogenic cells, control groups P1 and P2.

\begin{tabular}{llll}
\hline Variable & Treatment & Mean + SD & $\mathrm{p}$ \\
\hline First Weight & Control & $27.75 \pm 1.886$ & .732 \\
& P1 & $27.38 \pm 1.061$ & .732 \\
Last Weight & P2 & $27.50 \pm 1.926$ & .732 \\
& Control & $30.00 \pm 1.309$ & .000 \\
& P1 & $25.38 \pm 1.996$ & .000 \\
Spermatogonia & P2 & $30.13 \pm 1.246$ & .000 \\
& Control & $30.25 \pm 2.866$ & .000 \\
Spermatocytes & P1 & $20.63 \pm 1.302$ & .000 \\
& P2 & $41.50 \pm 1.414$ & .000 \\
Spermatids & Control & $57.38 \pm 2.615$ & .000 \\
& P1 & $41.63 \pm 3.110$ & .000 \\
& P2 & $62.25 \pm 1.389$ & .000 \\
& Control & $88.75 \pm 5.120$ & .000 \\
& P1 & $65.88 \pm 4.643$ & .000 \\
& P2 & $94.63 \pm 3.462$ & .000 \\
\hline
\end{tabular}

Based on the results of the analysis using the ANOVA test regarding the value of the average difference in body weight, and spermatogenic cells, the control group, P1, and P2 showed that administration of the extract caused a significant increase in final body weight $(\mathrm{P}<0.05)$, as well as an insignificant increase in spermatogenic cells in the $\mathrm{P} 2$ group $(\mathrm{P}<0.05)$ (Budiani et al., 2017; Fathoni et al., 2018). 


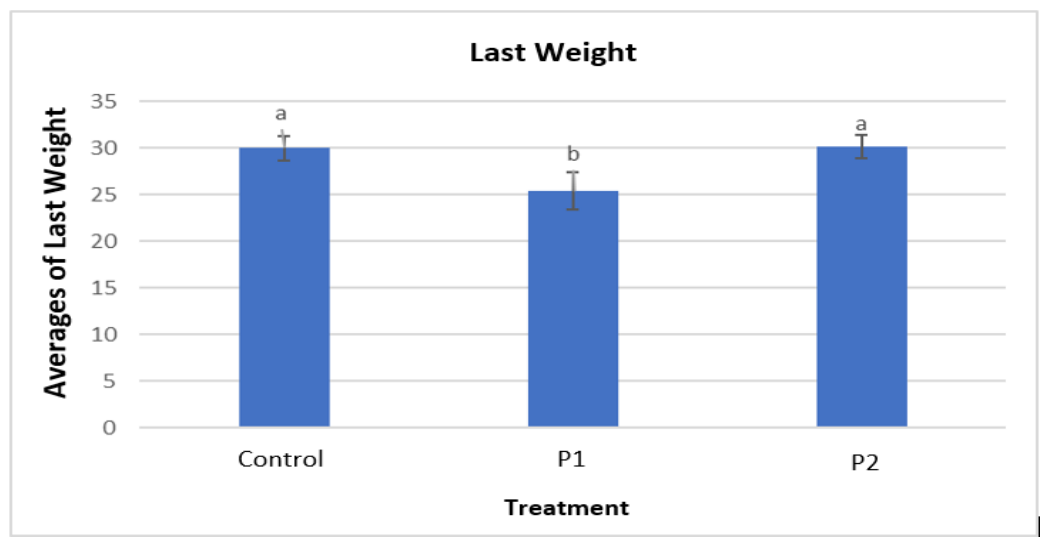

Figure 1. Effect of extract on final body weight

Where the value of an in Control and $\mathrm{P} 2$ shows insignificant results. While the letters a and $\mathrm{b}$ indicate a significant difference between the control group and P1 with a P-value $<0.05$.

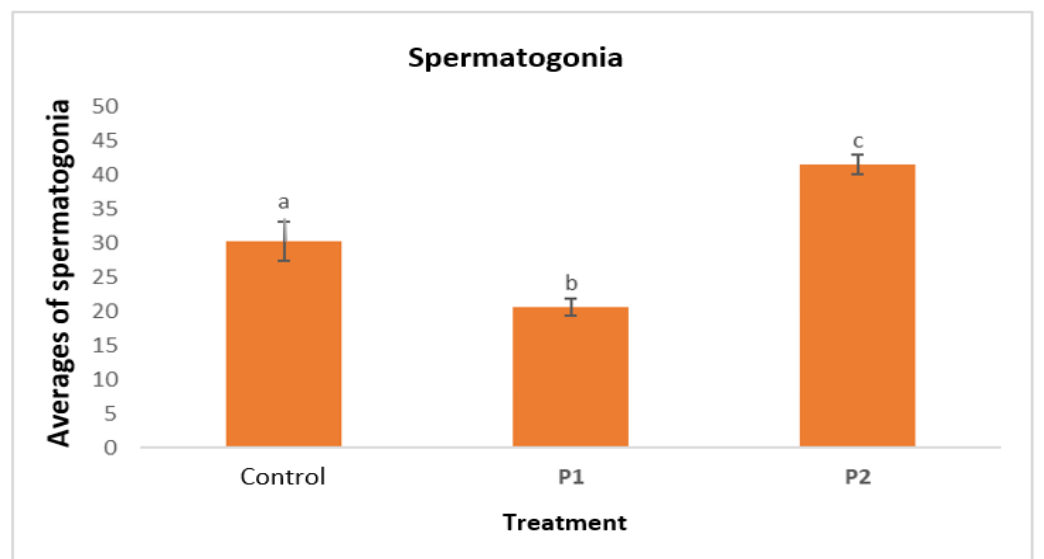

Figure 2. Effect of extract on spermatogonia cells

Where the letters $\mathrm{a}, \mathrm{b}$, and $\mathrm{c}$ indicate a significant difference between the control group with $\mathrm{P} 1$ and $\mathrm{P} 2$ with a Pvalue $<0.05$.

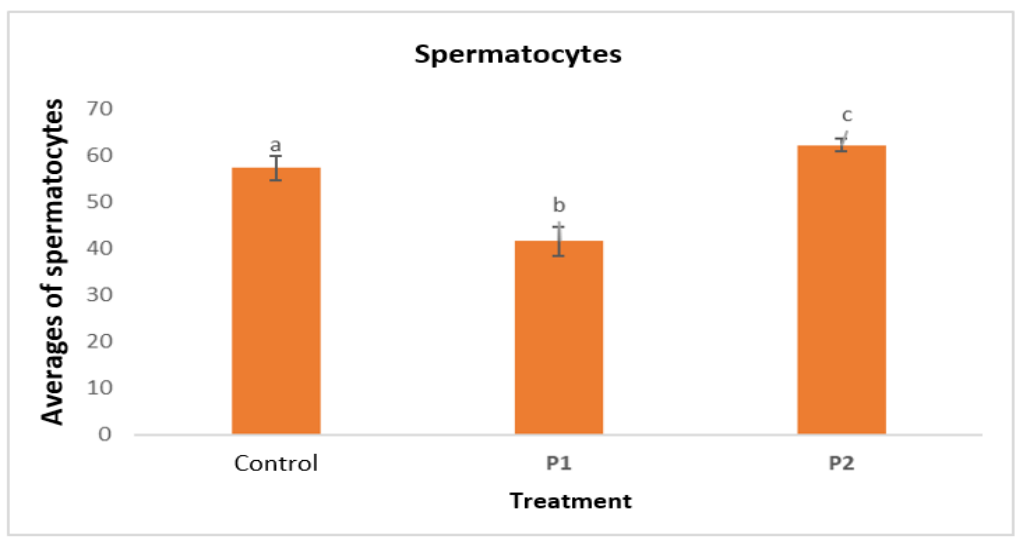

Figure 3. Effect of extract on spermatocyte cells

Where the letters $\mathrm{a}, \mathrm{b}$, and $\mathrm{c}$ indicate a significant difference between the control group with $\mathrm{P} 1$ and $\mathrm{P} 2$ with a Pvalue $<0.05$. 


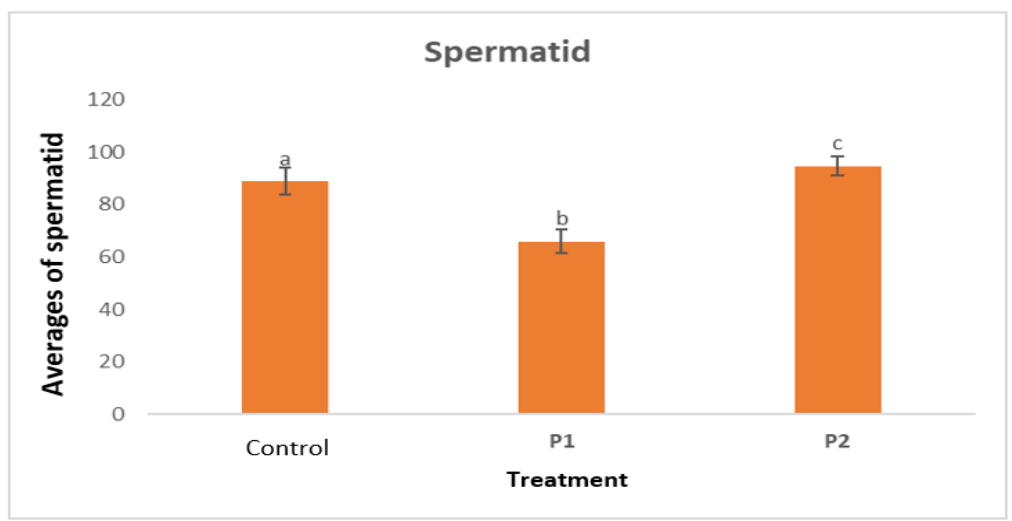

Figure 4. Effect of extract on spermatid cells

Where the letters $\mathrm{a}, \mathrm{b}$, and $\mathrm{c}$ indicate a significant difference between the control group with $\mathrm{P} 1$ and $\mathrm{P} 2$ with a Pvalue $<0.05$.

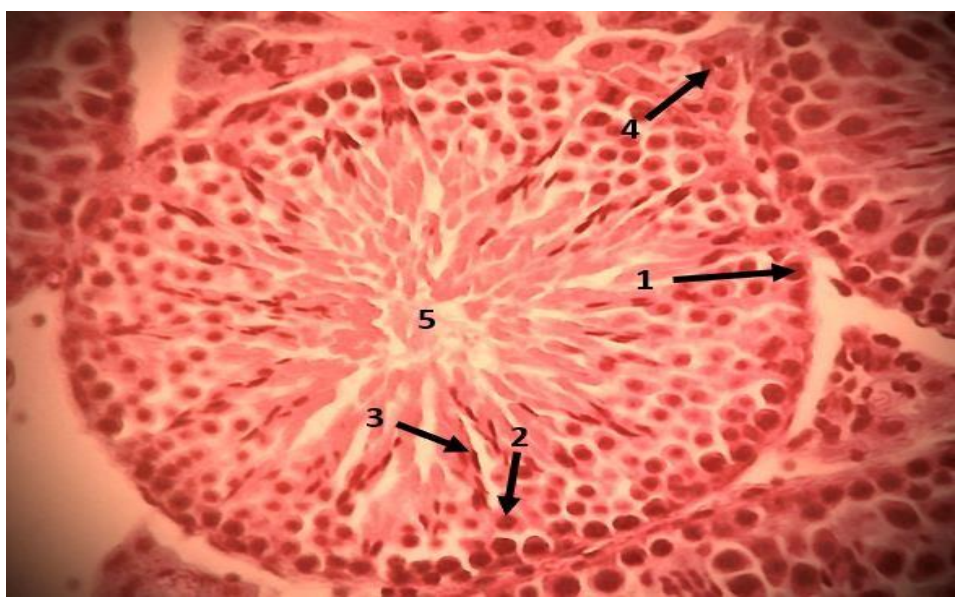

Figure 5. Cross-section of the seminiferous tubules of male mice testes

Description: (1) Spermatogonia, (2) Spermatocytes, (3) Spermatids, (4) Leydig cells, (5) Lumen of the seminiferous tubules

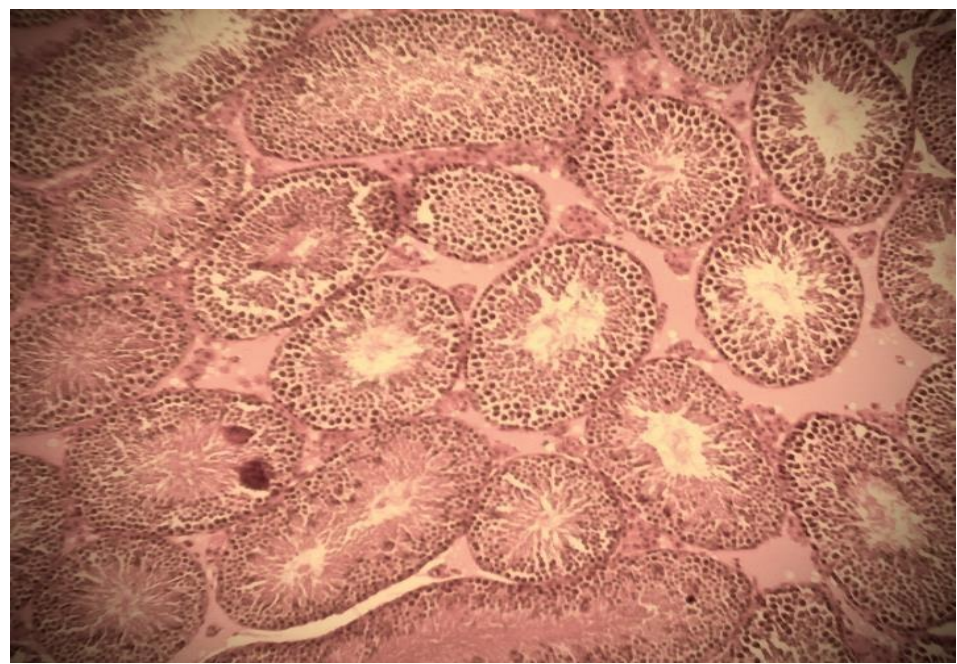

Figure 6. Cross-sectional incision of male mice's testes 


\section{Discussion}

The results of the study on the weight of the mice after being given treatment showed a significant difference in the control groups P1 and P2. The results of the study also showed that there was an increase in body weight in the P1 group where the $\mathrm{P} 1$ group was the lower group given alloxan. Growth hormone is a substance in the body that plays an important role in building muscle, stimulating cell growth, and developing and accelerating optimal bone growth. Growth hormone is produced more during sleep (especially at bedtime earlier). In this study, it is suspected that high blood sugar levels interfere with natural sleep time which is at risk of lowering the amount of growth hormone by about $70 \%$ of normal (Chari \& Colagar, 2011).

In this study, mice given starfruit leaf extract showed a significant increase in the number of spermatogenic cells and final body weight in the P2 group, this is evidenced by the results of the SPSS test using the One-Way ANOVA test with a $\mathrm{P}$ value $<0.05$. Starfruit leaves have active compounds that are efficacious as antidiabetics, namely flavonoids which have a mechanism of action that can inhibit glucose reabsorption from the kidneys (Garber et al., 2009; Yanagimachi, 2005). Phytochemical compounds contained in the ethanol extract of belimbing wuluh leaves have been identified which include saponins, tannins, steroids, flavonoids, and alkaloids. Total phenol and flavonoid levels of star fruit extract can be determined and have the potential to be a source of natural antioxidants and antiinflammatory because it has very strong antioxidant activity and shows anti-inflammatory activity (Hasim et al., 2019). In group P1 given alloxan showed a significant decrease in the number of spermatogenic cells with a P-value $<0.05$. Decrease in the number of spermatogenic cells in the P1 group. High blood sugar levels can cause disturbances in the physiological balance of ROS in the body, so antioxidants are needed to prevent ROS balance disorders.

High blood sugar levels can result in a decrease in sperm quality and affect the formation of spermatogenic cells in the seminiferous tubules (Auwal et al., 2013). The decrease in the number of spermatogenic cells occurs in the meiotic stage. As is known, FSH affects meiotic division (AbdEl-Moniem et al., 2015). In this meiotic division, namely at the prophase, I pakiten stage, where at this stage the crossing over process takes place which is susceptible to external factors. Toxic nicotine compounds may inhibit the work of enzymes in the testes, namely cytochrome P450 , and NADPH cytochrome P-450 reductase so that these nicotine compounds increase the toxicity of enzymes which result in inhibition of the release of the FSH hormone.

According to Johnson \& Everitt (1988), primary spermatocytes at this stage are easily damaged, so the opportunity for abnormalities in the chromosomal arrangement of primary spermatocytes due to the influence of hormonal factors such as a decrease in FSH is very large, so the number of spermatocyte cells produced decreases. Under normal conditions, the process of spermatogenesis will occur in the process of releasing gonadotropin hormones from the hypothalamus, so that it will stimulate the anterior pituitary to release other hormones, namely luteinizing hormone ( $\mathrm{LH})$ and follicle-stimulating hormone (FSH). These hormones play a role in the process of spermatogenesis (Khourdaji et al., 2018). Luteinizing hormone will then stimulate Leydig cells to secrete the hormones testosterone and dihydrotestosterone, while FSH will proceed to stimulate Sertoli cells in the seminiferous tubules to assist the process of spermatogenesis. However, if there is insulin deficiency or insulin insensitivity in diabetics, there will be changes in the endocrine hormone pathway in the negative feedback system to the anterior pituitary. This mechanism begins with the activity of converting the hormone testosterone into the hormone estrogen so that testosterone levels are getting lower. And this increase in estrogen triggers the anterior pituitary to reduce the secretion of LH and FSH hormones which results in impaired male reproductive function (Treviño et al., 2001; Serrano et al., 1999).

Hyperglycemia disrupts the work of the hormone insulin so that a lot of glucose accumulates in the bloodstream. Hyperglycemia and insulin deficiency can affect tissue structure or function. This hyperglycemia will increase Reactive Oxygen Species (ROS) which can disrupt spermatogenesis in the seminiferous tubules. Besides diabetes can disrupt spermatogenesis, it can also cause impaired function of the accessory sex glands. This event is associated with increased ROS. In people with diabetes mellitus, increased ROS can damage the mitochondrial membrane so that it loses the potential function of the mitochondrial membrane in inducing apoptosis of sperm cells (Dalimartha, 2004). The decrease in the number of spermatogonia cells, spermatocytes, and spermatids in the P1 treatment given alloxan was also caused by the high levels of ROS in the testes, resulting in damage to the cell membranes of the seminiferous tubules so that toxic free radicals can enter the seminiferous tubules. Increased levels of ROS will produce oxidative stress due to high levels of ROS and antioxidants are not able to reduce levels of oxidants, causing damage to cells, tissues, and organs.

This is in line with the histological abnormalities of the diabetic rat testes as evidenced by the research of Adelati et al. (2016). There are differences in testicular spermatogenesis between rats with diabetes mellitus and normal rats. 
The results of this study indicate that DM disease interferes with the process of spermatogenesis. In general, diabetes causes disturbances in sperm quality, especially movement or motility and number. High blood sugar in the body causes disturbances in blood vessels, especially those leading to the penis (Corona et al., 2016). This disorder causes blood flow to be not smooth to the penis so that nutrients for the development of spermatozoa in the seminiferous tubules are disrupted (Parhizkar et al., 2013). Spermatozoa that are formed in the testes require a large amount of energy from sugar that is absorbed by the body. Spermatozoa -men who have acute diabetes will usually experience a decrease in quality. There was a decrease in the number and impaired motility. The number will decrease and the movement will be disturbed.

The active substances found in star fruit leaves include saponins and flavonoids. Saponins function as antihyperglycemic agents by preventing glucose uptake at the brush border in the small intestine. While flavonoids are alpha glucosidases that function to delay carbohydrate absorption so that blood glucose levels will decrease.11 Flavonoids are one of the most common secondary metabolites found in plant tissue. Flavonoids belong to the class of phenolic compounds with a chemical structure of C6-C3-C6 (Figure 1). The flavonoid framework consists of an aromatic ring $\mathrm{B}$ and the middle ring is a heterocyclic containing oxygen.12,13 Figure 1. Flavonoid structure.14 Flavonoids work by denaturing proteins. This process also causes disturbances in the formation of cells, thereby changing the composition of protein components. Impaired cell membrane function can cause an increase in cell permeability, followed by bacterial cell damage (McCowen et al., 2001; Iacobellis et al., 2020). This damage causes bacterial cell death. Flavonoids function to maintain normal growth and defense against the effects of infection and

damage. Based on research conducted by Zurha et al. (2008), it was found that flavonoids have a strong antioxidant effect. The mechanism of action of flavonoids as antioxidants is to suppress the formation of ROS (Reactive Oxygen Species) by inhibiting enzymes in the formation of ROS and increasing regulation and protection of antioxidants. Flavonoids can also protect lipid membranes from oxidative damage, so that lipid peroxidation can be inhibited and increased levels of Malondialdehyde (MDA) can be prevented (Pushparaj et al., 2001; Pushparaj et al., 2000).

\section{Conclusion}

The conclusion that can be drawn from this study is that Averrhoa bilimbi leaf extract can increase the number of spermatogenic cells in male mice with hyperglycemia.

\section{References}

AbdEl-Moniem, M., Mustafa, H. N., Megahed, H. A., Agaibyi, M. H., Hegazy, G. A., \& El-Dabaa, M. A. (2015). The ameliorative potential of Hyphaene thebaica on streptozotocin-induced diabetic nephropathy. Folia morphologica, 74(4), 447-457.

Adelati, S., Juniarto, A. Z., \& Miranti, I. P. (2016). Histopatologi spermatogenesis testis tikus Wistar diabetes melitus (Doctoral dissertation, Diponegoro University).

Auwal, M., Sanda, K., Mairiga, I., Lawan, F., Mutah, A., Tijjani, A., ... \& Thaluvwa, A. (2013). The phytochemical, elemental and hematologic evaluation of crude mesocarp extract of Hyphaene thebaica (doumpalm) in wistar albino rats. Asian J. Biochem, 8(1), 14-23.

Budiani, N., Karmaya, N. M., Manuaba, I. P., \& Satriyasa, B. K. (2017). The Number of Leydig Cells, Sertoli Cells, and Spermatogonia are Lower towards a Little Rats that Their Parent Given Genistein during Periconception Period. International Research Journal of Engineering, IT \& Scientific Research (IRJEIS), 3(2), 1-8.

Chari, M. G., \& Colagar, A. H. (2011). Seminal plasma lipid peroxidation, total antioxidant capacity, and cigarette smoking in asthenoteratospermic men. Journal of Men's Health, 8(1), 43-49.

Corona, G., Giagulli, V. A., Maseroli, E., Vignozzi, L., Aversa, A., Zitzmann, M., ... \& Maggi, M. (2016). Testosterone supplementation and body composition: results from a meta-analysis of observational studies. Journal of endocrinological investigation, 39(9), 967-981.

Dalimartha, S. (2004). Ramuan Tradisional untuk Pengobatan Diabetes melitus, Dalam: Buku Ajar Fitokimia.

Fathoni, A., Adiputra, N., Pangkahila, J. A., \& Adiatmika, I. P. G. (2018). Reduction of levels postprandial blood glucose on medium intensity physical exercise in intervals and continues. International research journal of engineering, IT \& scientific research, 4(6), 10-32.

Garber, S. E., Shabahang, S., Escher, A. P., \& Torabinejad, M. (2009). The effect of hyperglycemia on pulpal healing in rats. Journal of endodontics, 35(1), 60-62. https://doi.org/10.1016/j.joen.2008.09.010

Gülçin, I. (2012). Antioxidant activity of food constituents: an overview. Archives of toxicology, 86(3), 345-391.

Hasim, H., Arifin, Y. Y., Andrianto, D., \& Faridah, D. N. (2019). Ekstrak Etanol Daun Belimbing Wuluh (Averrhoa bilimbi) sebagai Antioksidan dan Antiinflamasi. Jurnal Aplikasi Teknologi Pangan, 8(3), 86-93. 
Iacobellis, G., Penaherrera, C. A., Bermudez, L. E., \& Mizrachi, E. B. (2020). Admission hyperglycemia and radiological findings of SARS-CoV2 in patients with and without diabetes. Diabetes research and clinical practice, 164, 108185. https://doi.org/10.1016/j.diabres.2020.108185

Johnson, M. H., \& Everitt, B. J. (1988). Coitus and fertilization. Essential Reproduction. Blackwell.

Kaličanin, B., \& Velimirović, D. (2012). Potentiometric stripping analysis of zinc, cadmium and lead in tobacco leaves (Nicotiana Tabacum L.) and soil samples. Int J Electrochem Sci, 7, 313-323.

Kasturi, S. S., Tannir, J., \& Brannigan, R. E. (2008). The metabolic syndrome and male infertility. Journal of andrology, 29(3), 251-259.

Khourdaji, I., Lee, H., \& Smith, R. P. (2018). Frontiers in hormone therapy for male infertility. Translational andrology and urology, 7(Suppl 3), S353.

Kurup, S. B., \& Mini, S. (2017). Averrhoa bilimbi fruits attenuate hyperglycemia-mediated oxidative stress in streptozotocin-induced diabetic rats. Journal of food and drug analysis, 25(2), 360-368. https://doi.org/10.1016/j.jfda.2016.06.007

McCowen, K. C., Malhotra, A., \& Bistrian, B. R. (2001). Stress-induced hyperglycemia. Critical care clinics, 17(1), 107-124. https://doi.org/10.1016/S0749-0704(05)70154-8

Pala, F. S., \& Tabakçıŏlu, K. (2007). Free radicals: Our enemies or friends?.

Parhizkar, S., Yusoff, M. J., \& Dollah, M. A. (2013). Effect of Phaleria macrocarpa on sperm characteristics in adult rats. Advanced pharmaceutical bulletin, 3(2), 345.

Pushparaj, P. N., Tan, B. K. H., \& Tan, C. H. (2001). The mechanism of hypoglycemic action of the semi-purified fractions of Averrhoa bilimbi in streptozotocin-diabetic rats. Life Sciences, 70(5), 535-547. https://doi.org/10.1016/S0024-3205(01)01423-0

Pushparaj, P., Tan, C. H., \& Tan, B. K. H. (2000). Effects of Averrhoa bilimbi leaf extract on blood glucose and lipids in streptozotocin-diabetic rats. Journal of ethnopharmacology, 72(1-2), 69-76. https://doi.org/10.1016/S0378-8741(00)00200-2

Serrano, C. J., Treviño, C. L., Felix, R., \& Darszon, A. (1999). Voltage-dependent Ca2+ channel subunit expression and immunolocalization in mouse spermatogenic cells and sperm. FEBS letters, 462(1-2), 171-176. https://doi.org/10.1016/S0014-5793(99)01518-5

Sisein, E. A. (2014). Biochemistry of free radicals and antioxidants. Scholars Academic Journal of Biosciences, 2(2), 110-118.

Tan, B. K. H., Tan, C. H., \& Pushparaj, P. N. (2005). Anti-diabetic activity of the semi-purified fractions of Averrhoa bilimbi in high fat diet fed-streptozotocin-induced diabetic rats. Life sciences, 76(24), 2827-2839. https://doi.org/10.1016/j.lfs.2004.10.051

Treviño, C. L., Serrano, C. J., Beltrán, C., Felix, R., \& Darszon, A. (2001). Identification of mouse trp homologs and lipid rafts from spermatogenic cells and sperm. FEBS letters, 509(1), 119-125. https://doi.org/10.1016/S00145793(01)03134-9

Valko, M., Leibfritz, D., Moncol, J., Cronin, M. T., Mazur, M., \& Telser, J. (2007). Free radicals and antioxidants in normal physiological functions and human disease. The international journal of biochemistry \& cell biology, 39(1), 44-84.

Vicari, E., \& Calogero, A. E. (2001). Effects of treatment with carnitines in infertile patients with prostato-vesiculoepididymitis. Human Reproduction, 16(11), 2338-2342.

Yanagimachi, R. (2005). Intracytoplasmic injection of spermatozoa and spermatogenic cells: its biology and applications in humans and animals. Reproductive biomedicine online, 10(2), 247-288. https://doi.org/10.1016/S1472-6483(10)60947-9

Zuhra, C. F., Tarigan, J. B., \& Sihotang, H. (2008). Aktivitas antioksidan senyawa flavonoid dari daun katuk (Sauropus androgunus (L) Merr.). Jurnal Biologi Sumatera, 3(1), 7-10. 